\title{
Rio+20: A Missed Opportunity
}

Keshab Chandra Ratha

Lecturer, Saraswat Degree Mahavidyalaya (Sambalpur University), Godbhaga, PIN-768111, Dist-Sambalpur, Odisha, India. Email: keshab_ratha@rediffmail.com

\section{Sushanta Kumar Mahapatra}

\begin{abstract}
Post-Doctoral Fellow (India for European Union-Erasmus Mundus Programme) at Department of Economics Science, University of Bologna, Strada Maggiore 45 - 40125, Bologna, Italy, Office 19, Associate Professor (Economics), Amrita School of Business, Amrita University, Amrita Institute of Medical Science (AIMS) Campus, Ponekkara Post, Kochi-682 041, Kerala, India, Email: sushanta.mahapatra@gmail.com;sushanta_mahapatra@asb.kochi.amrita.edu
\end{abstract}

\section{Doi:10.5901/ajis.2014.v3n3p0139}

\section{Abstract}

The Rio + 20 were a landmark event in addressing serious environment \& economic crisis affecting the world. The Earth summit was a historical opportunity to set the world on correct development trajectory. Negotiators from 191 countries came together to chart a road map for sustainable development and poverty eradication. But the developed and developing countries could not wipe out their differences and reach consensus on the definition of green economy. The new draft was in favour of developed countries .The current draft agreement is bereft of necessary vision and commitment for eradicating poverty and tackling environmental degradation to deliver sustainable development. The document is still empty and very weak in addressing daunting and grave concerns of women, youth and children, farmers, indigenous people and workers. It has failed in addressing the reproductive and sexual rights of women. There are no strong commitments to women's rights to land, property and inheritance. The main objective of this paper is to explore that how Rio +20 has become a victim of reduced commitments by developed countries to support the developing countries in the quest of their development. This paper is an academic endeavor to reflect that how the summit is a missed opportunity to tackle the most important environmental issues. There is an increasing rift between fashionable environmental issues focused on by rich countries and the prosaic needs of the rest of the world. The document is an offense to the future generation since the governments have agreed to maintain the status quo on so many issues that will severally effect the future generation. The document is a far cry from the ambitious response to world's mounting social, economic and environmental crisis. It has missed the opportunity to shift global agriculture onto a path towards ecological sustainability and justice for the hungry.

\section{The Context}

The world is facing a mounting crisis .Nature is being subjected to unprecedented destruction and loss due to the relentless plundering of its resources. Everyday we depend on the diversity of plants animals for our food, fuel, clothing, medicines and raw materials. In recent years, the global financial crisis, food crisis, volatile oil price, degradation of ecosystem combined together resulted in the intensity of the problem to a considerable extent. These multiple and inter-related crisis call into the question the ability of a growing human population to live peacefully and sustainably on this planet of the demand the urgent attention of the governments and citizens around the world. The systemic crisis is food, fuel, finance that come to a head and is on-going in many countries -have their roots in an economic paradigm that has not accounted for the value of nature and its array of life supporting services. There is no core recognition that the multiple crisis that we face are caused by current anthropocentric development model rooted in unsustainable product and consumption patterns and financialisation of economy that are all based on and exacerbate gender, race and class inequities.

No any positive advance in the negotiations process going on within official conference was found. The discussion was confirmed to a set of take proposals concerning the implementation of new international environmental governance. The Green economy is more stage of capitalistic accumulations. Nothing any green economy substitutes the economy based on extraction of fossil fuels, or models of consumption or industrial production. On the contrary, this economy opens up new territories to the economy that exploits people and environment, increasing the myth that unlimited economic growth is possible. The failed economic model which is dressed in green submits all vital cycles of nature to the market rules \& to the domination of technology. Tran genies, agro-toxics, synthetic biology, artificial life, geo-engineering \& nuclear energy are narrated as technological solutions to the multiple crises even though they do not address the real causes ${ }^{1}$. Furthermore, the expansion of agro industrial food system, one of the biggest causes of environmental, economic and social crisis is promoted, deepening speculation about food and promoting the interests of global agribusiness industry at the expense of local, peasant, family, indigenous peoples productions, thus affecting the health of all. The formal process proposes to implement forms of global environmental

\footnotetext{
1 rio20.net/en/documents/the--issues-at-rio
} 
governance, which role would be to administer and facilitate this "green economy" through the World Bank and other financial institutions which would result in a new cycle of debt and structural adjustment dressed in green. There can not be democratic global governance without ending the influence of corporations on the United Nation².

The Earth summit was a historical opportunity to set the world on correct development trajectory. Negotiators from 191 countries came together to chart a road map for sustainable development and poverty eradication. The theme was green economy. But developed and developing countries denied to wipe out their differences. Developed countries were not prepared to avoid their extravagant way of living, while developing countries somehow stood firmly on their green commitments. The countries could not reach consensus on the definition of green economy. The outcome was a document which neither showed the ways for saving the environment nor ways to alleviate poverty. There had been agreement on less then 25 per cent of the draft compiled by the United Nations. On June 15, 2012, the last informal negotiations, when the co-chairs reported that very little progress have been made.

The new draft favored developed countries. The Indian negotiators had made the reporters realize by convincing developed countries to keep the phrase "Common But Differentiated Responsibility"in the draft. Some countries held the view that though the outcome is balanced, it is not ambitious. By midnight, all issues barring those of high seas and self-determination of people under foreign occupation had been decided. It was about four in the morning when the text was agreed upon finally. The next day, the agreed draft was printed by Brazilian Presidency and circulated among negotiators. But it could not be called as a conference document as it had not yet been formally adopted by a plenary. Unlike previous UN conferences, while all the negotiations drafts were released to the public despite being under deliberations, the text was marked by utter secrecy. The Brazilian government left no stone unturned working on the draft, but it disagreed to obtain premature comments from the nongovernment organizations \& activists. The outcome did not satisfy all. Outside the negotiation chambers, the civil society groups slammed the outcome document as one without ambitions. Some even called the conference Rio minus 40 because they viewed the outcome as regressive. Some negotiators said they had agreed with a spirit of compromise. It did not give enough considerations to the circumstances of each country. The European Union required setting ambitious targets \& action-oriented goals for each country. It hided it under phases of green economy as a tool for sustainable development. The aim was to set green targets under which economic and development parameters could be gauged.

China and Japan were unhappy. The African union which forms an integral part of G77+ China and the European Union wanted that the United Nations Environmental Programme (UNEP) turned into a specialized UN body in the lines of UNDP or UNICEF. They wanted it to be called United Nations Environment Organization. The strong opposition of the US, Brazil, India, China \& some other countries made the African Countries to withdraw their demands. Japan held the outcome as not ideal. China was unhappy with the section on trade measures and technology transfer. The US was dejected that the reproductive rights of women were not recognized and priority themes for sustainable development had not been finalized. Although the high level meeting came 20 years after the $1^{\text {st }}$ Earth summit, a majority of 17 principles chartered in 1992 have not progressed, with many areas of concern experiencing rapid degradation. The main principles laid fourth at the Earth Summit of 1992 have been rampantly broken to the point that today's levels of green house gases are rising more rapidly than before the U.N convention on climate change came into being. In the year 1992, sustainability had 3 legs; economic prosperity, social equality and environmental protection. There is a leg missing. It is the leg of democratic participation, the voice of people. Rio+20 have an elongated economic leg that makes the sustainability table a rather wobbly affair. The economic leg offered in Green economy opens up the path for co modification of nature and poses the critical problem of the proposal. The UNEP's analysis of green economic agenda suggests that the only way to ensure sustainability is by getting the economy right which is fundamentally wrong.

\section{Alluring Promises on Green Economy}

The United Nations is showcasing the alluring promise of a green economy focused on global warming. The summit is wrong headed \& wrong targeted along with severe negligence of environmental concerns of the vast majority of the world. The term green economy was coined prior to the first earth summit in 1992 to provide links between economics and sustainability. But now it has gained a new impetus in a world where climate change is already a reality, commodity prices are rising and basic resources such as clean air, arable land and fresh water are increasingly scarce. As recently released report "Towards a green economypathway to sustainable Development and poverty Eradications" shows the market economy as currently constituted has resulted in the misallocation of capital in an unprecedented scale. The challenge ahead is to reconcile the emerging economic reality with the social values and ethics needed to produce a balanced and an inclusive green economy.

Global warming is by no means our main environmental threat. The deaths caused from floods, droughts, heat waves and storms amount to just 0.06 per cent of all deaths in developing countries. In comparison, 13 per cent of all third world deaths

\footnotetext{
${ }^{2}$ For detailed description see http:/rio20.net/en/documents/the issues-at-rio
} 
result from water and air pollutions. A highest number of people die from health problem that result from lack of clean water, sanitation, from breathing smoke generated by burning dirty fuels indoors and from breathing polluted air outdoors. The UN provides an amateur narration of the summit along with instances of its envisioned green economy in action. We see scary pictures of dry river beds along with plenty of pretty solutions like wind turbines and solar panels. In a world where billions people go to bad hungry, and where six million die each year from air and water pollutions in the developing world likely have a different set of priorities for their future. In this context we can say the leaflet of UN "The future we want" is a matter of irony. The leaflet cheerfully claims that China's shift to a low carbon growth strategy based on the development of renewable energy sources has created jobs, income and revenue. Over the past 25 years, China has quadrupled its $\mathrm{CO}_{2}$ emission. China's decades long economic expansion has lifted 600 million of people out of poverty, but the enormous pollution that it has entailed does not fit into Rio+20's green narrative. In a world played by serious problems caused by air and water pollution, the breezy focus on unrealistic solution is deeply disturbing. The green growth is more like green washed growth-a merely cosmetic change to the business-asusual approach that gave as global financial crisis and that perpetuates poverty and exacerbates inequality.

The current draft agreement is lacking of any sense of necessary vision and commitment required to tackle the twin challenges of eradicating poverty and tackling environmental degradation to deliver sustainable development. It has no clear tangible objectives, time frames or financial commitments to solve pressing global challenges such as climate change, food insecurity and gender inequality. The climate change, food insecurity and unequal distribution of rights are pressing burden shouldered by the poorest people. They are increasingly affected by mere severe disasters such as floods or droughts. They have limited safety nets to rely on in times of hardship. The women and girls are most vulnerable people who are often responsible for providing food and water to their families. They have no rights to own land and participate in decisions that affect their lives. We can deliver equity and social justice for poor women and men through tackling food insecurity and gender inequality. Unequal rights, lack of opportunities and access to resources remain as serious obstacles to social and economic development of the world's poorest people. Building resilience for poor families and to protect their lives and livelihood from climate change impacts and other shocks is essential to overcome poverty. There is lack of ambition and urgency by global leaders to tackle these important challenges ${ }^{3}$.

The Rio+20 does not commit on extractive industries. It forces indigenous people out of their homes \& endangers their livelihoods, refusing their right to dignity. It supports conditional transfer of technology which will exclude millions of youth from accessing the opportunities of decent work \& fail to address the issue of armed conflict. The ordinary people's perspectives, concerns, issues and views are simply out weighted by politics of aid/finances/conditionality's and subsidies. The summit is a missed opportunity to tackle the most important environmental issues. The UN and countless politicians have chosen to focus on trendy issues like global warming and a green economy instead of important issues like air and water pollution. Nine hundred millions people are malnourished; one billion lack clean drinking water, 2.6 billion lack sanitation, and1.6 billion lack electricity. Every year, about 15 million people die from diseases. While the rich countries are worrying about global warming and enamored with alluring solutions, there are far more important environmental issues at stake for the third world. Today's crucial environmental problems of air and water pollution leave six millions people dead every year. There is an increasing rift between fashionable environmental issues focused on by rich countries and the prosaic needs of the rest of the world 4 .

Critics have argued that today's green economic policies only make minor carbon reductions at a very high cost \& promise million of jobs with large subsidies. This in turn raises costs for the rest of the economy \& causes on the equal or greater number of job losses elsewhere. The green economy framework does not consider immediate concerns of developing world like malnourishment, lack of sanitation, clean drinking water, communicable \& neglected diseases. $13 \%$ of all deaths the developing world is attributable to air \& water pollution 5 .

The green economy was included as one of the two key themes of the conference, but without a common understanding of the meaning of the term. The EU was one of the key exponents of its introduction and was keen to see what it called a green economy roadmap - with targets, indicators and goals adopted at the summit. Developing countries and many in civil society expressed concerns that the term green economy was being used to replace the agreed multilateral conceptual framework for sustainable development. Further to this, the developing countries expressed concerns that these negotiations might pave the way for environmental issues to be used as the basis of trade protectionism. Whilst in the UK context, the term 'green economy' is regularly used to refer to incentives for low carbon development, internationally it is being used to drive the expansion of activities that enable environmentally negative activities to expand-such as monoculture tree planting, the growth of bio fuels, increased carbon offsetting and the setting up new markets in biodiversity and forests. This is often led by multinational

\footnotetext{
${ }^{3}$ www.care-international-org/media-Releases/rio-20-conference-world-connot-grow-at-the-exprese-or-poor-people.html.

${ }^{4}$ http://www.telegraph.co.uk/news/obituaries/

${ }^{5}$ Ong Suan Ee - S. Rajaratnam School of International studies, Singapore."After Rio+20: What Is The Future We Want"
} 
companies which are focused on the brown economy, but who are using the opportunity of Rio to green wash their activities. Chapter 2 fails to set out how regulatory frameworks could and should be used to phase out unsustainable economic activity. Regulation is merely recognized as one of a 'mix of measures' alongside voluntary and other approaches

\section{Centralized Global Economy}

Rio+20 assured "inclusive and sustainable" economic growth without putting forward proposals or changes to the dominant economic system.. The Green economy is one more stage of capitalistic accumulation. This economy opened new territories to the economy that exploited people and environment. Since 1992, the global economy has become more accumulative and centralized which goes against the principle of sustainable development goals. A series of crisis such as climate, food, power, energy and financial emerged due to over-exploitation of national resources, over consumption and the capitalist nature of economy. Most of the world resources are in the hands of around 5 per cent of the richest people. In the past two decades, the rich and poor gulf has increased. The development goals must assert social and economic equality and environmental protection. The green economy can not solve the problem until the current architecture is changed.

Rio is minus 20 meaning thereby the summit was more a step back than anything else. The political trenches between industrialized world and the developing countries remain as deep as before. Many conflicts have largely remained unsolved, but even more complex in the meanwhile. Due to the consensus principle applied in UN conferences like Rio, a disagreeing party needs to be convinced and can not simply be outvoted. This causes international negotiating processes to be slow and painful. The decisions on environment and development need to come with major structural and financial implications in order to have any effect 6 .

\section{Non-Inclusive and Non-Participatory Conference}

The document is an offense to the future generation since the governments have agreed to maintain the status quo on so many issues that will severally effect the future generation. No doubt, the civil society was given an opportunity to bring proposals to the table but no heed was paid on them. Majority of political leaders come only for a family picture and a complaisant speech in front of an almost empty plenary without further engaging with their colleagues on sustainable development issues. It is an missed opportunity even to launch a dialogue at the highest political level. The Brazilian president and conference host Dilma Rousseff declared that Rio+20 was the most inclusive and participatory conference in history and a global expression of democracy. But in the final days of negotiations, civil society groups were shut out of the official conversations. The calls for greater participation were ignored and after some secret closed-door meetings, Brazilian facilitators produced the final text with no possibility for alteration. The document was a far cry from the ambitious response to world's mounting social, economic and environmental crisis. Originally, the UN had promised each of civil society participatory groups the chance to give a 2 minute final symbolic statement. Sadly speaking, in the last day of conference, the civil society groups were barred from making any final statements ${ }^{7}$.

\section{Less Emphasis on Sustainable Consumption Patterns}

There is need to reduce food waste and post-harvest losses. The relevant provision of the document has failed to address the issue with sufficient priority and urgency given that 1.3 billion tons of food or one third of global food production is wasted each year. It has missed the opportunity to shift global agriculture onto a path towards ecological sustainability and justice for the hungry. It has not provided sufficient and appropriate context for sustainable develop goals to guide the future development processes $^{8}$. It is revisiting of the 1992 first Earth summit to reassess priorities and formulate action to ensure sustainable development. The major problem in these twenty years has been the failure of the governments to implement their commitments which is especially true of rich countries.

\section{Less Importance on Access to Universal Energy}

Development, a once-a-decade meeting aimed at reconciling economic and environmental aspirations, has produced a nonbinding declaration, committing the world's politicians to modest goals. The proposals set out at the beginning, such as providing universal energy access and doubling renewable by 2030 , have been left on the cutting room floor. The Rio +20 outcome document does not give governments the urgently necessary framework to shift financial resources away from unsustainable and inequitable energy systems to necessary investments in decentralized renewable energy systems. Although there is welcome recognition that renewable technology and energy efficiency are necessary for sustainable development, there are not targets of timescales and no real indication of how transformation will occur, including no mention of technology transfer or finance. None of

\footnotetext{
${ }^{6}$ www.rioplus twenties.org/3 p-1289

${ }^{7}$ http//searching for sustainability.blogspot.in/2012/06/reflections-on-rio-20-resistance-of.html

${ }^{8} \mathrm{http}: / /$ www.e-alliance.ch/en/s/food/rio-plus/20/
} 
the provides either the vision or mechanisms to enable the poorest communities and the countries to 'leap frog' the dirty energy development pathways followed by the rich, industrialized countries. Paragraph 129 "notes" the launch of UN Secretary General's "Sustainable Energy for All" initiative. This initiative does not form part of the official summit process. It was welcomed in the earlier draft, but has now only been noted. The initiative is attempting to address the challenges of climate change and poverty, but its targets lack ambitions and the process had been corporate led, with little participation of civil society or the people it is purporting to help.

\section{Rolling Back of Women Rights}

The women worldwide are outraged that the governments failed to recognize women's reproductive rights as a central aspect of gender equality and sustainable development. Reproductive rights are universally recognized as human rights. There were no strong commitments to women's rights to land, property and inheritance. The critical connection between climate change and gender is not mentioned at all. Women, children, indigenous people and the impoverished are heavily impacted by increasingly dire consequences of climate change. Equally critical is potential contribution to climate mitigation and adaption that could be made by women, yet their essential role in leading and participating in desperately needed climate solutions is not mentioned. The text of twenty years ago was again reiterated and reinforced. The document is still empty and extremely weak in addressing daunting and grove concerns of women, youth and children, farmers, indigenous people and workers. It has failed in addressing the reproductive and sexual rights of women.

The women major group is dismayed and alarmed that there is no reference to radioactive pollution and its devastating impact on our health and our environment, including rivers, foods and air. They called for immediate shutdown of nuclear power. In many countries of the world, women produce up to 80 per cent of the food, cultivating land that they do not own, gathering foods from forests to which they have no entitlements. The rush for resources along with minerals \& bio-fuels has removed a vast number of women from their lands which were cultivated by them for years together. The women demanded an immediate interruption to land grabbing.

There are no concrete measures to assure women's rights to access to and control of natural resources that are the basis of their livelihoods. Women are disappointed that the document does not clearly ensure free, prior and informed consent for all communities impacted by so called Green Economy investments. Women demand "no go Zones "for mining, agro-fuel and forestry companies. In order to ensure that women, indigenous peoples and local communities have access and control over water resources, women call for no privatization of water resources. Women are very concerned about increased focus in private financing and decrease of public revenue for sustainable development. There is no commitment for new financial mechanisms such as Financial Transaction Tax. The women called for elimination of subsidies, including indirect subsidies that caused negative effects in eco-systems \& local communities. The Rio +20 has not set up stronger governance for sustainable development. Women call for a seat for a representative of civil society's women organizations in the expert penal for the SDGs. There is the need of Rio+20 to take concrete measures to fully implement women's rights and women's leadership and to protect the rights of the most vulnerable members of our societies ${ }^{9}$.

There is reference to women's "unpaid work" but without recognizing the unequal and unfair burden that women carry in sustaining care and well-being. This is further exacerbated in times of economic and ecological crisis when women's unpaid labour acts as a stabilizer and their burden increases. Reference to the root causes of excessive food price volatility, including its structural causes, is not linked to the risks and burdens that are disproportionately borne by women. Development is not sustainable if care and social reproduction are not recognized as intrinsically linked with the productive economy and reflected in macro-economic policy making. Reference is made to the critical role that rural women play in food security through traditional sustainable agricultural practices including traditional seed supply systems. These are of severe indication of future danger unless the government stops giving importance on export-oriented agribusiness. The wrong headed policies are not properly addressed due to corporate interests that are protected in the Rio +20 outcome. The Northern governments supporting for such corporate interests have covered the sustainability paradigm in so called green economy. Their attitude is tilted towards the economic pillar, emphasizing sustainable eco-growth over equitable development \& without any ecological limits. Within this section, women were treated as supplier of labour, but not recognized as right holders. While the Rio principles including common but differentiated responsibilities are reaffirmed at Rio+20, the outcome is imbalanced across the three pillars of sustainable development without sufficient attention to gender and social justice, including women's rights. It fails to tackle the systemic inequalities of the international monetary, financial and trading systems; and prioritizes economic growth over the ecology and equity. No progress and commitments for women's rights and rights of future generation in sustainable development was found in the document ${ }^{10}$.

\footnotetext{
${ }^{9}$ Rio +20 , women's major Group United Nations Rio +20 summit

${ }^{10} \mathrm{http}: / /$ www.pambazuka.org/en/category/features/83215/print
} 


\section{Reduced Commitments by Developed Countries and Lack of Transparency}

The agreed draft was printed by the Brazilian presidency and circulated among the negotiators. But it could not be called as a conference document as it had not yet been formally adopted by a plenary. Unlike UN previous conference where all negotiation drafts were open to public despite being under deliberation, this text was marked by utter confidentiality. The Brazilian government left no stone unturned working on the draft, but it disagreed to obtain premature comments from the non-government organizations \& activists. The civil society groups slammed the document as one without ambition. As the outcome is regressive, they viewed the conference Rio minus 40 . Although this summit came after twenty years, a majority of 17 principles chartered in 1992 have not progressed, with many areas of concerns experiencing rapid degradation. It is the largest suicide note in history. Nothing is new and specific .The U.S refused to be bound by any international standards that will affect its citizens and their choices. The fast growing economies like India, Brazil, China and South Africa disagreed to curb that would affect their rate of growth. The poorest nations still find a way out their acute poverty and environmental disasters that visit them with regularity. The green economic policies are more ambiguity without any specific programme or plan. In 1992's Rio conference, the principle of common but differentiated responsibility was enshrined in the Rio declaration but not everyone endorsed it. The United States refused to accept the Kyoto proposal or endorse Biodiversity convention. The economies of the industrialized world were in stable. Hence, they were willing to make some financial commitments to assist the developing countries. Today, the industrialized North is in trouble, preoccupied with its own economic crisis. In the present summit, these countries were silent on committing funds ${ }^{11}$.

It was discouraging that there was more talk than action about the pre-negotiated document. It was a far cry from a success. The Rio +20 falls short of justified expectations in addressing serious environmental and economic crisis afflicting the world. Rio +20 has become a victim of reduced commitments by developed countries to support the developing countries in the quest of their development.

\section{Jargons and Repetitions in Zero Draft}

There are strong pressures to accommodate the desires of various governments and interests to make sure that their issues or concerns are at least mentioned. The few potential gems of the zero draft are lost in the devulge of vague promises. Based on the record of four decades, there is little guarantee that the governments will follow through on these negotiated grand plans. The "zero" draft is a preliminary version. The '19' page Zero draft titled as "the future we want" has too much jargon and repetition, many abstract incremental promises and goals. Given the experience with past UN mega-conferences, there is a real danger that by the time the leaders get to Rio, they will be asked to endorse a document that will have ballooned in length to more than 100 pages $^{12}$.

\section{Disagreements in Sustainable Development Goals}

There was a disagreement, principally between the developed and developing countries, as to how to decide which issues or "themes". Many developed countries wanted to see a focus in environmental goals while developing countries wanted the goals to reflect all three pillars of sustainable development-economic, social as well as environmental. The second major division was it the SDGs were to be "universal goals" subject to Rio principles and in particular Common but Differentiated Responsibilities (CBDR). The US and EU argued strongly that these goals should not be subject to the Rio principles and specifically CBDR. The compromise had been to launch a negotiating process to agree them in the run up to 2015 which noted that they were to be based on Rio principles but did not explicitly mention CBDR.

\section{Absence of International Financial Architecture}

On the positive side, the section of chapter six recognizes the importance of enhancing financial support to help developing countries for sustainable development, but there is only one reference to new and additional finance is with regard to south south and triangular co-operation and nothing to suggest that there will be new finance from the north to south. Paragraph 263 offers some useful wording on debt restructuring, debt relief and financing although it would have been stronger if debt "prevention and resolution" had been explicitly mentioned. It is not paragraph 258 and 259 in improving the quality and the quantity of Overseas Development Aid (ODA). Aid architecture is important; but there is a glaring absence of most international financial architecture areas such as; capital flows and controls, financial and trade policy space, macro-economic policy conditions, financial regulations and the role of banks, the international monetary system and global reserves and financialization of foods, commodities and nature. Paragraph 266 stresses the importance of fighting corruptions and illicit financial flows but

\footnotetext{
11 Cited from EPW editorial (2012)

${ }^{12} \mathrm{http}: / /$ switchboard.nrdc.org/blogs/ijcherr/the greatest challenge of 2012.html
} 
incredibly, does not mention accountability mechanisms or monitoring of the private or public sector ${ }^{13}$.

\section{Weak Political will and Presence of Corporate Interests}

The Rio +20 was fully a reflection of weak political will of developed countries to provide enhanced means for developing countries in respect of implementing the objectives of green economy. Many countries including India rejected the unilateral measures \& trade barriers under the guise of green economy. Green economy should be bottom-up \& democratized. The cost of green development should be affordable for the poor. The summit did not include a call to end subsidies for fossil fuels. The countries gathered together reaffirmed the need to achieve sustainable development without mandating how, reaffirmed commitment to strengthening international co-operation just not right now; \& reaffirmed the need to achieve economic stability with no new funding for the poorest nations ${ }^{14}$.

The corporate-driven agenda remained a rising threat to people \& nature. It was a prescriptive green economy road map aggressively pushed by developed countries. The so-called green economy was based upon fossil fuels, destruction of environment by establishing extractive industries \& other capitalist investments. The various multinational corporations like Oil Giant Shell were active in lobbying at Rio +20 . The green economy was used for increasing markets in the guise of using natural resources as driver of growth that would lead the way for financialization of nature. More corporations moved against the people's rights, democracy and nature, kidnapping the common property of mankind to save the financial-economic system . Transnational corporations continued to commit their crimes with the flagrant violation of the rights of people and nature with impunity. Likewise, they used to advance their interests through militarization, criminalization of livelihoods of people and social movements promoting deterritorialization in the field and in the city . It would cause the plunder of world's remaining natural wealth \& privatization of critical services, products \& technologies through public-private partnerships.

\section{Summing Up}

Most of it repeats promises made at previous earth summits and in some cases omits key references because attempts by some countries to step back from previous commitments. What is completely lacking is the vision or ambition that characterized the original Rio Summit in 1992 or anything that will challenge the systemic nature of the environment, development and economic crisis. What is critical now is for an open and transparent process, including civil society, to negotiate a set of appropriate SDGs that make up for the vision and ambitions that has been missing in Rio. What the Summit should have done is reviewed progress on the sustainable development agenda over the last 20 years, identified gaps, and what steps are needed to address them. Such a process would have identified that failure of mainstream economic policies to operate within environmental limits or in the interests of majority of the world's population.

\section{References}

EPW editorial (2012): "Rio plus nothing", Economic and Political Weekly, June 30, Vol XLVII Nos 26 \& 27, pp.7-8

Friends of the Earth (2012): "Rio +20: Is this it?!, Initial analysis of Final Draft Text", Briefing, 20 th June, Friends of the Earth England, Wales and $\mathrm{N}$ Ireland (http://www.circleofblue.org/waternews/wp-content/uploads/2012/07/Friends-of-the-Earth-Rio+20-Is-this-it-initial-analysis.pdf, accressed on 12 November 2012) http//searching for sustainability.blogspot.in/2012/06/reflections-on-rio-20-resistance-of.html, accessed on 29th July 2012

http://switchboard.nrdc.org/blogs/ijcherr/the greatest challenge of 2012.html, accessed on $30^{\text {th }}$ December 2012

http://www.e-alliance.ch/en/s/food/rio-plus/20/, accessed on $10^{\text {th }}$ January 2013

http://www.pambazuka.org/en/category/features/83215/print, accessed on $15^{\text {th }}$ September 2012

http://www.telegraph.co.uk/news/obituaries/, accessed on $9^{\text {th }}$ August 2012

http://www.un.org/millenniumgoals/

http://www.uncsd2012.org/rio20/,

http://www.unep.org/greeneconomy,

http:/rio20.net/en/documents/the issues-at-rio, accessed on $5^{\text {th }}$ July 2012

Jayaraman, T (2012): "Holding Back the'Green Economy' Idea, But for How Long?" Economic \& Political Weekly, July 14, Vol XLVII, No 28.

Kadekodi, Gopal K (2012): "Is a 'Green Economy' Possible?" Economic \& Political Weekly, June 22, Vol XLVIII, No 25.

Ong Suan Ee (undated) S. Rajaratnam School of International studies, Singapore."After Rio+20: What Is The Future We Want"

Rio+20, women's major Group United Nations Rio +20 summit, accessed on $8^{\text {th }}$ February 2013

Sanwal, Mukul (2012): "Global Sustainable Development Goals the Unresolved Questions for Rio+20”, Economic \& Political Weekly, 18 February, Vol XLVII, No 7.

UN, UNCTAD and UNEP (undated): The Transition to a Green Economy: Benefits, Challenges and Risks from a Sustainable Development Perspective, Report by a Panel of Experts* to Second Preparatory Committee Meeting for United Nations Conference on Sustainable Development Prepared under the direction of: Division for Sustainable Development, UN-DESA United Nations Environment Programme UN Conference on Trade and Development.

United Nations, General Assembly (September 2012): "Sixty-Sixth Session, Agenda Item 19, Resolution adopted by the General Assembly 66/288", Annex: The future we want

www.care-international-org/media-Releases/rio-20-conference-world-connot-grow-at-the-exprese-or-poor-people.html, accessed on 12 July 2012 www.rioplus twenties.org/3 p-1289, accessed on $26^{\text {th }}$ July 2012

\footnotetext{
${ }^{13}$ Further discussion see Friends of the Earth (2012):

${ }^{14} \mathrm{http}$ ://www.idahostateman.com/2012/06/23/2165811/rio-20-the-unhappy-environmental.html.
} 